\title{
Task-based Methods and iPad Materials for Active Learning
}

\section{Kazumi Kato \\ Tokai University}

\section{Reference Data:}

Kato, K. (2019). Task-based methods and iPad materials for active learning. In P. Clements, A. Krause, \& P. Bennett (Eds.), Diversity and inclusion. Tokyo: JALT.

When Japanese students try task-based group work in their classes, they often rely on their first language. To solve this problem, I asked UK university students to do the same task-based group work, recorded their interactions, and created a model video. Using the video materials, I designed a methodology for teaching group work. The unique points of the method are as follows: First, the students in Japan recorded their own task-based group work with iPads, analyzed it, and compared it to the model video. Second, the students wrote down Japanese expressions they would like to say in English during the discussion and the teacher created an input activity according to their needs. Finally, the students tried the same task with different group members and gave feedback on their communication skills. This paper introduces model video materials and methodology and presents potential implications for future study.

日本人英語学習者が英語でグループ活動を行う際、いまだ日本語が飛び交う傾向が多く、タスク活動の後のプレゼンテ一 ションのみ英語を使用する場合が多い。その問題を解決するため、著者はイギリスの大学にてグループ活動の様子を録画し モデルビデオを作成した。さらにそのビデオ教材を利用してグループ活動のための指導法を作成した。この指導法の特徵は、 日本人学習者が自身のグループ活動の様子を動画に録画しモデルビデオと比較分析しフィードバックができること、日本人英 語学習者がグループ活動中に「言いたかった英語表現」を提出し、教師が英訳して配布することによって学生のニーズに応え ていること、学生が異なるグループのメンバーで再度同じグループ活動を行い、書き起こしをしてフィードバックをしているこ とである。本稿では、日本人学習者が英語で円滑にグループ活動を行うための教材と教授法を紹介し、英語による円滑なグル 一プ活動を目指す。

n 2014, the Japanese Ministry of Education, Culture, Sports, Science and Technology (MEXT) proposed the "English Education Reform Plan corresponding to Globalization" and required English teachers to conduct their classes in English with high-level linguistic activities including but not limited to presentations, debates, and negotiations. They also required proactive and cooperative learning and instruction methods, which is the basis of active learning (MEXT, 2014). According to Swain (2005), pair-work or group-work tasks using L2 are only possible for students who have sufficient communicative skills in the L2. If the learners do not have these skills, they will need to use their mother tongue to complete the tasks and, as a result, might produce very little L2. When I conduct my university classes and give students task-based group projects, students with low levels of English proficiency tend to use Japanese when doing these projects. When the tasks become more complex, students use Japanese more often during group work. For example, some students do not understand my instructions in English so they first need to confirm what they should do in a group with other group members in Japanese. Students often mention that they do not know how to say words and phrases in English during group work. That frustration may lead to a lack of interest in or motivation toward using English. Therefore, they end up finishing the task in Japanese. The students who are good at English give the presentations in English in front of the entire class, and all feel they have completed the task. It is quite difficult for teachers to know who did and did not do an assigned task within a group. Since taskbased learning must focus on the process rather than the product (Richard \& Rogers, 2001), I became both concerned about and interested in how teachers can help students use English as part of a group discussion process. In the attempt to solve these issues, I considered providing students with special training for group work at the beginning of the semester.

There are two goals for the training sessions. One is to create iPad materials to grab students' attention and motivate them. The other is to create a new methodology using the iPad material and meet students' needs in terms of engaging in effective group discussion. I hypothesized that if students understand how to conduct group work with the model videos and acquire useful English expressions by input-based training, they might use the knowledge and English as a tool to engage in group work. For this 
hypothesis, I first selected a task suitable for video recording group work. Then I went to the UK to video record students abroad, conducting the same group work as the students studying in Japan. Using the video data, I made authentic model video materials for iPads. I also created task-based learning methodology for group work. The points of the method are as follows: First, Japanese students recorded their communications in groups with iPads, analyzed them, and compared their discussions with the model video. Second, students collected English expressions from the video and in their own groups. They made a list of expressions they wanted to use during group work, then they submitted them to me and I translated them with the help of a native English teacher. Finally, students tried the same group work with different group members and gave feedback on their communication skills and language acquisition. Lessons using authentic video materials and methodology were conducted in 15 classes in total at two different universities in Japan with several modifications.

\section{Task-Based Language Teaching}

According to Ellis and Shintani (2014), task-based language teaching aims to develop learners' communicative competence by engaging them in meaning-focused communication through the performance of tasks. In addition, the task must satisfy four criteria: First, the primary focus should be on meaning. Second, they should have some kind of gap (i.e., a need to convey information, to express an opinion, or to infer meaning). Third, learners should largely rely on their own resources. Fourth, there is a clearly defined outcome other than the use of language. In short, English is not only meaning but also the method to go beyond language acquisition so that students can use the language as a tool to communicate with others effectively. There are several kinds of task clarifications and Wills (1996) showed six kinds of pedagogic classifications: listening, ordering and sorting, comparing, problem-solving, sharing personal experiences, and creative tasks. In this paper, creative tasks in which students make their own stories were used. These tasks are categorized into unfocused tasks and focused tasks. Unfocused tasks are tasks designed to provide learners with opportunities for using language. On the other hand, focused tasks are tasks designed to provide opportunities for communication using specific linguistic features like grammar rules, but those features must be hidden in the task (Lyster, 2007). Using this methodology, the teacher does not provide linguistic features but gives students opportunities to identify the grammar rules by themselves.

I considered these criteria and classifications then selected a creative task called Picture Stories (Miura, Nakashima, \& Ikeoka) for group work. The procedure of this task is as follows: First, students choose four pictures out of six and make a story by themselves. Second, after they make their own stories, they make a group of four. Students show their own stories to the group members, and they make one big story in a group. Third, they present their stories to the other groups in class. In this task, the focus is on making a story with group members; students need to use English as a communication tool.

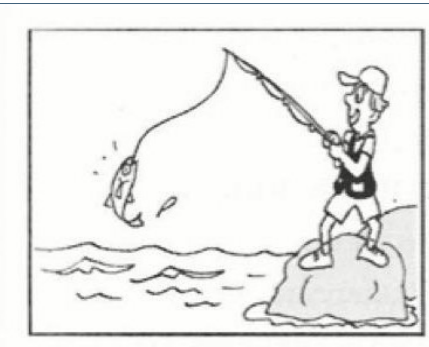

A

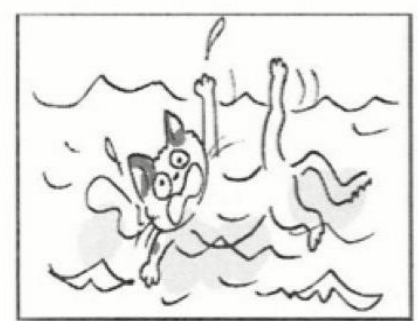

$\mathrm{D}$

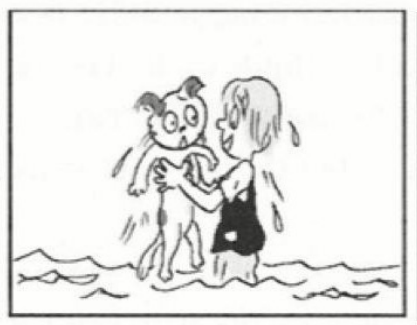

B

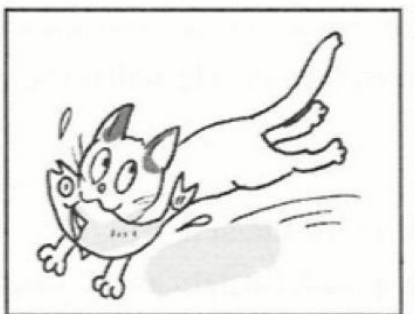

E

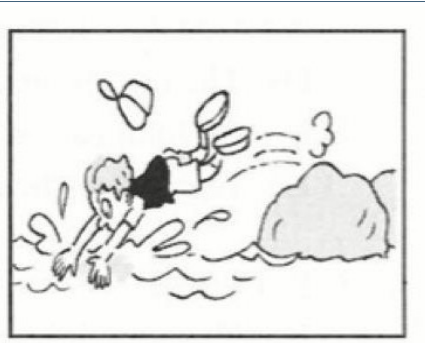

$\mathrm{C}$

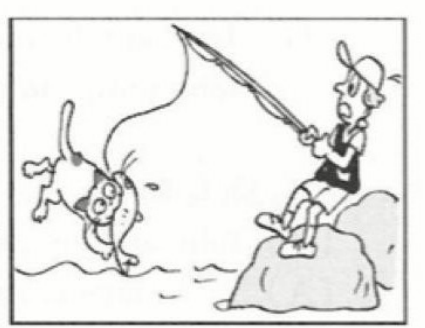

$\mathrm{F}$
Figure 1. Picture Stories used in the activity. Adapted from Miura, Nakashima, \& Ikeoka, 2006, p. 87. Reprinted with permission.

\section{Video Materials}

I chose a college in the U.K. to video record group work done by native English speakers using the Picture Stories task. Since I have been visiting the college for a cultural communication program for more than 10 years and have a good relationship with teachers and students, they warmly accepted my request to conduct the tasks. I explained the purpose of this project and how to conduct the task. I then asked them to sign consent forms. Sixteen college students who are of the same age as most of the Japanese 
university students, around 19 years old, agreed to conduct the task. They first chose four out of six pictures by themselves made a story with them in English, their L1. Then they made groups of four. Before the main task started, they chatted about an easy topic to relax and counteract the fact they were being video recorded. They then conducted the picture story task in their groups. I video recorded four different group members' data. After returning to Japan, I selected the best video data-those in which all four students can be seen on the screen with no one invading the recording. I then edited the data and created model video materials for the Japanese students. I added an explanation of this task at the opening of the video and made two different versions of the model: one with Japanese captions and the other without captions. The video materials were installed onto iPads.

\section{Methodology}

Part of the methodology for language acquisition for this task involves the use of Picture Story. In previous work, I created a second language and pragmatic acquisition structure (SL \& PA) for group work (Figure 2). The acquisition structure was adapted from the SLA studies of Ellis (2008) and lzumi (2009), a study of interlanguage pragmatics (ILP) forms from Martinez-Flor (2010), and previous research on pragmatics by Kato (2014). The study of ILP is to investigate how nonnative speakers understand and perform linguistic action in a target language and how they acquire L2 pragmatic knowledge (Kasper, 1996). ILP has mainly focused on the comparison of differences between $L 2$ learners' production of speech acts and the speech acts of English-speaking students. The research of ILP has mainly focused on request, apology, refusal, praise, and complaint expressions; I found that these expressions can all appear in the Picture Stories task. So, I added analysis activities to this structure to help students develop pragmatic awareness. I also included writing activities to encourage students to express what they noticed during group work.

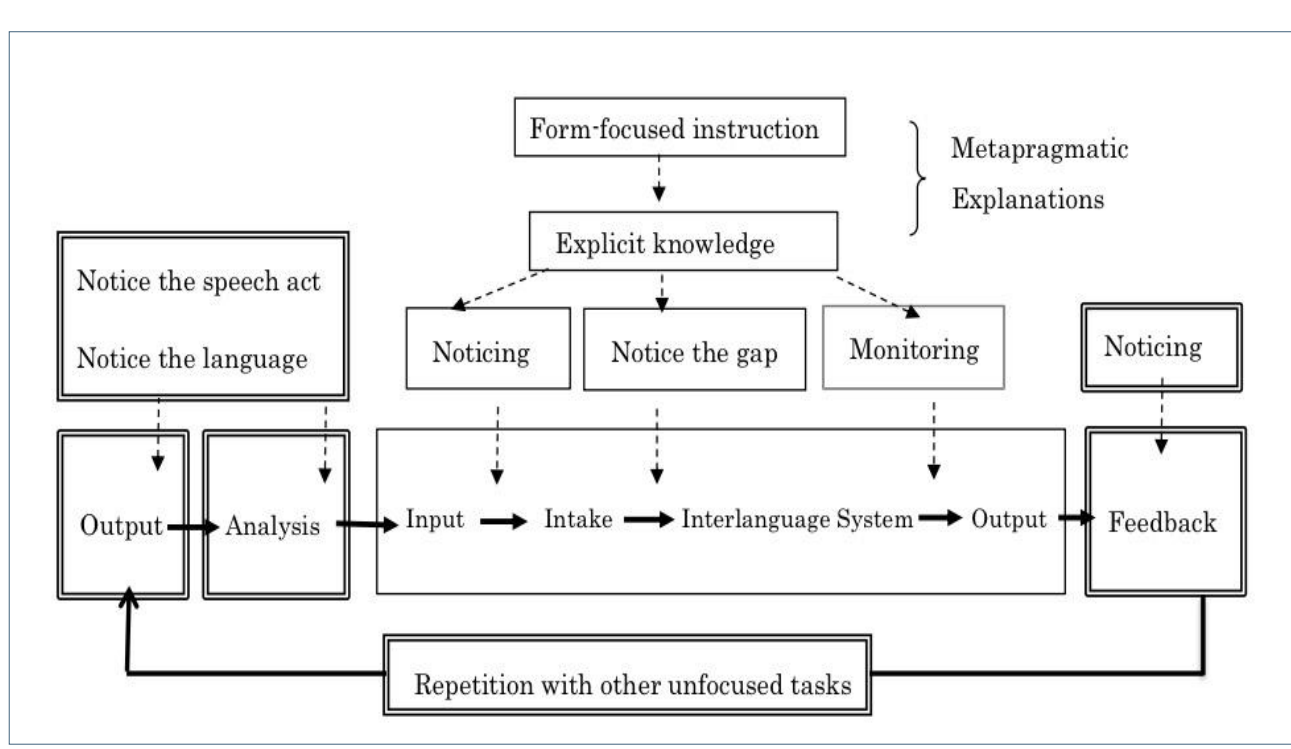

Figure 2. Structure for second language and pragmatic acquisition (Kato, 2016b, p. 201). This flowchart is an English adaptation of the flowchart offered in Japanese by Kato.

\section{Procedure}

The entire procedure takes 5 days to complete and each lesson includes several subtasks (see Table 1). Students complete small subtasks step-by-step toward the final goal of conducting group work in English. On Day 1, students focus on output to become aware of how much English they already know. First, individual students create a story with four pictures by themselves in 20 minutes (subtask 1); then they make a group of four. In the group, each student introduces their own story; they discuss and create a better story (subtask 2). While they are conducting group work, they record their group discussion on iPads, and at the same time, they write down the expressions they want to say in English during group discussion. Students hand in the list of the expressions, and work with a colleague who is a native English teacher to translate the Japanese expressions into English expressions and make an input handout.

On Day 2, students study analysis with pragmatic aspects. The Japanese students watch the video of a model group discussion conducted by the U.K. students without subtitles. While the students watch the video, they answer some questions such as, "What the relationship of the four people in the model video?" Answers can be chosen 
from a list that includes family members, classmates, boyfriends and girlfriends, teachers and students, among others. It is obvious that they are all classmates, based on their appearance. However, that question tends to lead students to notice that the social relationship is one of the key items of the pragmatic aspects they need to be aware of. According to Kato's (2004) pragmatic research, English expressions are different depending on the social relationship. So, this question that English expressions in the model video are also suitable for Japanese students. Another question focused on what kinds of strategies the U.K. students used frequently. In this question, the Japanese students ordered 10 speech acts (requests, offers, suggestions, guesses, apologies, complaints, compliments, refusals, agreements, and disagreements) according to how frequently they were used in the video. I created these 10 speech acts by referring to the 15-speech acts sample (Rylander, Clark, \& Derrah, 2013). The question also leads students to notice the communication patterns in a group and also made them notice English grammar rules. Other questions were open-ended questions such as what the major differences were between their group work and the model group work, and how students in Japan can conduct group discussions better. After the Japanese students analyzed the model video without subtitles, they received a dictation handout for listening homework (subtask 4). The model video was uploaded on YouTube, so students could watch it (see Figure 3) and fill in the blanks as listening practice at home (see Appendix A).

\section{国: . . . (2)

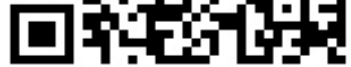

Figure 3. Video of listening practice homework assignment (https://www.youtube.com/ watch?v=9upldxabH8s\&feature=youtu.be).
On Day 3, students checked the dictation answers while watching a second video with featured English expressions (https://www.youtube.com/watch?v=m8_b8RsoKtQ) installed on their iPads. After they finished checking the answers, they checked the meanings and wrote them down. The handout (see Appendix B) has two vertical sections and students wrote in English in the left section and in Japanese on the right. They also discussed what the grammar rules are and how to memorize the expressions. This activity can be conducted in Japanese, depending on the students' English proficiency level, because they are focusing on the grammar rules. The students then practiced in pairs to memorize these expressions. One of the pair quizzed in Japanese and the other answered in English. They also had another opportunity to input English expressions by giving quizzes within their assigned groups. I gave back the input handout with additional translations. Using the input handout, students practiced input-based activities (subtask 5). Each student had different English expressions in their input handout, and they were able to exchange and obtain new expressions by communicating with classmates. This session focused on input-based tasks and this activity should lead to students' grammatical understanding. According to Ellis and Shintani (2014), the input-based tasks enable learners to develop not only the ability to comprehend input but also the grammatical resources they will need to speak and write. It is also important to recognize that learners do not need grammar to perform simple tasks. This means L2 acquisition does not begin with grammar but with a basic variety that is essentially lexical.

On Day 4, students tried the group work again with the same task with new members and recorded their discussions on iPads (subtask 6). When they use the same picture story task, they felt that the task was easier than what they had done on Day 1. They had more opportunities to use the expressions that they acquired with the input-based activity with their input handout. I took into consideration the possibility that repetition with different members can motivate students to try to use English again.

On the final day, students transcribed their group discussion with group members, watched recorded videos on their iPads, and typed their conversations on their computers. They highlighted the English expressions they used from the input handout. They could visibly confirm if they could or could not acquire and produce English expressions as their feedback (subtask 7). 
Table 1. Methodology for a Group Discussion Lesson

\begin{tabular}{lll}
\hline Day & Purpose & Style \\
\hline Day 1 & Output & Individual
\end{tabular}

Subtasks Students' activity

Make a story with 4 pictures.

Make a story with group members and record the group discussion on an iPad.

Write down expressions they wanted to say in English and submit to the teacher.

Day 2 Analyz (pragmatic)

Listening

input

Day 3 Analyze

(linguistic)

Input

Intake

Interlanguage

system
Group

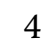

Group

Pair

Analyze linguistic rules and try input activities using model video and translated English expressions.

$\begin{array}{llll}\text { Day } 4 \text { Output } & \text { Group } \quad 6 & \begin{array}{l}\text { Make a story with group members and } \\ \text { try the same task again, recording on } \\ \text { iPad. }\end{array} \\ \text { Day } 5 \text { Feedback } & \text { Group } \quad 7 & \begin{array}{l}\text { Transcribe the group discussion. Note } \\ \text { any improvement. }\end{array}\end{array}$

\section{Implementation}

The 5-day training procedure based on the methodology was conducted in 15 different university classes with different English proficiency levels over 6 years. I conducted lessons in various classes: one listening and speaking class, one business English class, seven writing classes, and six presentation classes. Over the years there were several modifications based on trial and error. Some universities had a total of 15 lessons in one semester while others had 30 lessons in one semester. I allocated 5 days for the procedure using the methodology. Although the training lessons were completed in five sessions, some classes did not have enough time for feedback for students to transcribe the group discussion and see their improvement (subtask 7). In this case, I gave students the transcribing task as homework. I uploaded their videos to YouTube and sent each group of students the URLs. Students were able to watch their recorded videos online. They transcribed their group discussion at home, and they sent them to me via email attachment. In writing classes, students wrote their findings as their writing assignment and sent them to me.

From these special training lessons, several interesting findings emerged. From the aspect of pragmatics, students with both low and high English proficiency were able to identify different communication patterns for group work when comparing themselves to students in the U.K. For example, students were able to find turn-taking differences (subtask 3). They found that students in the U.K. interrupt while the other members are still talking. On the other hand, Japanese students tend to wait for people to finish talking before they speak. Students in the U.K. nodded and used gestures a lot. but students in Japan did not.

I found that students find such differences in speech acts highly interesting, and that may be an indication that the activity is fostering their illocutionary competence (see Bachman \& Palmer, 1996). Kato (2015) found that there were no major differences in illocutionary competence between students with low and high proficiency in English. However, the number of expressions they wanted to learn was a difference: Students need different expressions depending on their English proficiency levels. When students submitted the expressions list, they would like to use (subtask 2), students with low English proficiency tended to ask a few simple English expressions such as, "What are you doing?" "What are we doing now?" "You two decide," or "You go first." These expressions are requests rather than the actual content of the tasks. They want to know the present situation and need group members' help. On the other hand, students who are highly proficient in English tend to ask many complex expressions or state their opinions in detail and reflect on the videos with more depth. Comments included "Your story is better," "The transitions are becoming strange," and "The expression 'hurry' seems like a cat's feeling." These differences suggest that students have different needs depending on their proficiency levels and teachers need to know what they desire to learn.

From my observation with iPad recording data, I was able to observe the students' improvement in motivation. For example, the student who requested how to say 
"You two decide" in English had low motivation for participating in group work at the beginning. He slept during group work and did not say anything at all. However, through this methodology, he learned the English expressions to convey his feelings, and once he used the expressions, he could participate. He used expressions such as "It's your turn" and started participating in group work with different members. This may suggest that he was finally able to become involved in group work because he acquired English expressions which he wanted to use (see Kato 2016b).

These observations were further evidence that students have different needs; teachers should not just give them useful expression lists but identify students' needs along with their proficiency level. In subtask 5, highly proficient students showed the potential of analyzing and finding the grammar rules or appropriate expressions by themselves. For example, some students discovered that the expression "Isn't this better" can be more modest than "Is this better?" Other students in the same group found that "Shall we?" seemed to be considering other people's opinions but when the U.K. speakers wanted to insist on their own opinions, they chose to use "Let's" instead of "Shall we?" Since Japanese students with high levels of English proficiency, such as those having a TOEIC score of over 500, have enough lexical knowledge for acquiring grammar and pragmatics by themselves (Kato, 2016a), teachers should not just teach grammar but should provide opportunities to discuss grammar.

On the other hand, students with low levels of proficiency had difficulties in finding the grammar rules by themselves so I put all English expressions into an Excel file, put them in alphabetical order, and made handouts. This method helped motivate the lower proficiency students. Teachers can provide support in helping them to recognize patterns and rules related to grammar (Kato, 2016b). In a writing class, one student mentioned in her journal that she became used to making sentences using grammar rules and enjoyed talking with group members. Another student mentioned that she felt her speaking skills improved. These comments show that many of the students were satisfied with this new methodology.

\section{Conclusion}

This paper introduced iPad materials and the methodology for group work in English. The Picture Stories materials are easy tasks for group work, primarily because the tasks are not focused on grammar but rather on communication skills. In addition, using the model video materials after the task and following the new methodology with SL \& PA, students learned how to conduct group work in English. The feedback can motivate them to use more English in groups. This special 5-day training session can be useful for other classes as well. However, there are some limitations with this 5-day training. Students did not have enough time to input English expressions during the semester as they needed to work on other activities in their English courses. I believe that when they have more time for input, they can use more expressions in groups. As Ellis and Shintani (2014) held, the acquisition of the grammar of a language is slow but TBLT is ideal for situations when there are only limited communicative opportunities outside of the classroom. So, I carefully considered ways to create long-term input-based materials that students can use outside of the classroom. The classroom can be a place to practice following the outside input. In 2018, I started using Google Forms for collecting expressions from students and used Quizlet, another online application, to make online materials. With these online applications, students can enjoy playing input games anytime outside of the classroom with a smartphone. Moreover, I was able to shorten my preparation time. Using various kinds of information and communication technology (ICT), I am currently studying the effect of long-term input materials because there are some limitations in acquisition with the limited number of possible class sessions. I can say that using ICT such as iPads, Google Form, and Quizlet is at least useful to identify students' needs and for making materials. The iPad video recording is also beneficial for teachers to check if all students are involved in group work. I continue to refine my method that helps students notice their weak points and motivates them to try using English during group work.

\section{Bio Data}

Kazumi Kato is a lecturer at Tokai University, School of Marine Science and Technology, Shimizu campus. Her research interests are interlanguage pragmatics, speech acts, task-based language teaching, cooperative learning, and humanistic English language education. She is also interested in ESP and has found opportunities for her students to use authentic English in a port near her university. <kazumilk@tokai-u.jp>

\section{References}

Bachman, L. F., \& Palmer, A. S. (1996). Language testing in practice. Oxford, England: Oxford University Press.

Ellis, R. (2008). The study of second language acquisition (2nd ed). Oxford, England: Oxford University Press.

Ellis, R., \& Shintani, N. (2014). Exploring language pedagogy through second language acquisition Research. New York, NY: Routledge. 
Izumi, S. (2009).「フォーカスオンフォーム」を取り入れた新しい英語教育 [New English education using focus on form]. Tokyo: Taishukan.

Kasper, G. (1996). Introduction: Interlanguage pragmatics in SLA. Studies in Second Language Acquisition, 18(2), 145-148. https://doi.org/10.1017/s0272263100014856

Kato. K. (2004). Comparison of refusal expressions by native speakers of English and Japanese learners (Unpublished master's thesis). Shizuoka University, Shizuoka, Japan.

Kato, K. (2015). グループ活動を英語で一英語母語話者のグループ活動をモデルにした教材一 [How to conduct group work in English: Using video materials with native English speakers]. JASELE, 44, 157-162.

Kato, K. (2016a).グループ活動を英語でーグループ活動の分析を題材としたライティング授業ー [How to conduct group work in English: A writing lesson using video analysis]. JASELE, 45, 177-184

Kato, K. (2016b). 小グループが英語で打ち合わせ、英語でプレゼンテーションできる指導一ネイティブ・スピー カーのグループ活動から学ぶー [Learning how to do small group discussions and give presentations in English from a model video of native English speakers]. In T. Miura (Ed.), 高校英語授業を知的に したい [We want to make high school English lessons intellectually] (pp. 198-228). Tokyo: Kenkyusha. Lyster, R. (2007). Learning a teaching language through content: A counterbalanced approach. Amsterdam, the Netherlands: John Benjamins.

Martinez-Flor, A. (2010). Suggestions. In A. Martinez-Flor \& E. Usó-Juan (Eds.), How social norms affect pragmatic behavior speech act performance (pp. 257-274). Amsterdam, the Netherlands: John Benjamins.

MEXT (2014). English education reform plan corresponding to globalization. Retrieved from http:// www.mext.go.jp/en/news/topics/detail/__icsFiles/afieldfile/2014/01/23/1343591_1.pdf

Miura, T., Nakashima, Y., \& Ikeoka, S. (2006). ヒューマンな英語授業をしたい! [I want to conduct humanistic classes]. Tokyo: Taishukan.

Richard, J. C., \& Rogers, T. S. (2001). Approaches and methods in language teaching. Cambridge, England: Cambridge University Press.

Rylander. J, Clark. P, \& Derrah. R. (2013). A video-based method of assessing pragmatic awareness. In J. Ross \& G. Kasper (Eds.), Assessing second language pragmatics (pp. 65-97). Hampshire, England: Palgrave Macmillan.

Swain, M. (2005). The output hypothesis: Theory and research. In E. Hinkel (Ed.), Handbook of research in second language teaching and learning (pp. 471-473). Mahwah, NJ: Erlbaum.

Wills, J. (1996). A framework for task-based learning. Harlow, England: Longman.

\section{Appendix A}

Listening Practice Homework

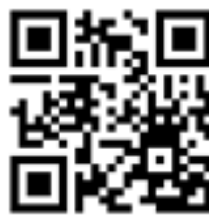

Group discussion part
71. Chloe

72. Adam:

73. Lottie:

74. Adam:

75. Chloe:

76. Adam:

77. Chloe:

78. Adam:

79. Chloe:

80. Adam

81. Chloe:

82. Adam:

83. Chloe:

84. Adam

85. Chloe:

86. Lottie:
Yes.

Yes.

Yes, we're in

Ok, so I think we'll ... Yes.

(

Um...

So that's D.

Yeah.

so That's ready. Ok.

( ), (

Alright... ( ) $),(\quad)($

then probably put them together to make a one big story.

Eventually the cat let go and fell to its death drowning horribly.

Umm... What will we do with mine?

()()$)$.

Oh, I like, "One day a man went fishing by the seaside because it was a nice sunny day." It's just a vacation why that man is out there.

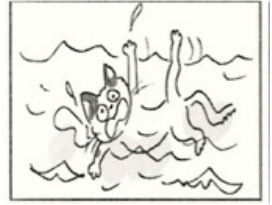

)(

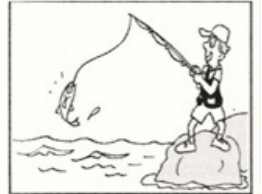

) 
87. Chloe:

88. Lottie:

A.

would Ilike ...

It was a surprise. He didn't just catch a fish,

he also caught a cat...

89. Adam:

90. Chloe:

91. Seb:

92. Adam:

93. Lottie:.

94. Adam:

95. Seb:

96. Lottie:

97. Adam:

98. Chloe:

99. Chloe:

100. Lottie:

Yeah. ,

) .

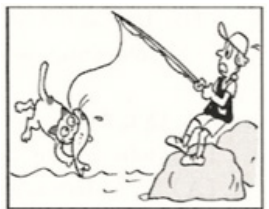

109. Adam:

And then, Seb?

This made the man fall...fall in after the cat and fish. But the cat...

( ), ( ) $)$.

It doesn't really work. What else would you got, Seb?

()$\quad() \quad$ ) that cat... the weight of the cat pulled...

No, we need to stick to this

Yeah. ()$)(\quad)(\quad)(\quad)$

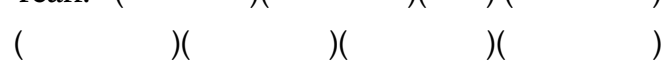

You've got to pick differently from your lines.

Maybe we should...

Maybe the one where you caught yourself on the

fishing rod?

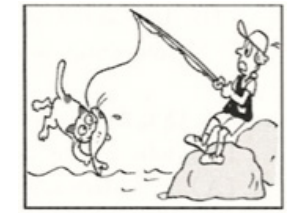

101. Adam:

Yeah. What have you got for, umm...

()$)(\quad)$

Read sentences out to us

102. Seb:

The cat was jumping Neko about with his fish in his mouth.

After a while, Neko's fish...

103. Adam: Could we...

104. Lottie: How about the

105. Seb:

106. Adam:

Caught a ...

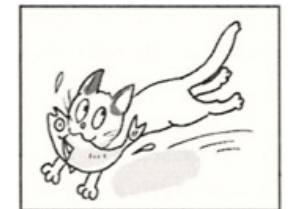

We could do that one first, then that there. So then, "One day

Neko the cat. Whatever the cat's called, I can't say..

Say the first sentence.

107. Seb:
108. Lottie:

110. Lottie:

111. Chloe:

112. Lottie:

113. Adam:

114. Chloe:

115. Adam:

116. Lottie:

117. Chloe:

118. Adam:

119. Lottie:

Alright. So, go, "One sunny day, blah, blah, blah...

Yeah.

The ca... Um...

$(\quad)(\quad)(x)($

...cat was jumping around, but at this thing, surprised, he actually caught the bones.

Ahh. And then out of nowhere, the cat was... Yeah.

No, he's from her-his..

Yeah, because he's got that one. I reckon the cat is having a great old time.

And then the fisherman's...

$\mathrm{Ok}$

then that's your line, and then,

It's his line saying that, her line

Yeah, so we goes

"One sunny day a man went fishing by the seaside

because it was a nice day. Neko the cat, was swimming about with a fish in his mouth, but at the fisherman's surprise, he got a fish...got a cat plus a fish... and then.

120. Chloe:

121. Adam:

122. Chloe:

Ooh.

Eventually the cat let go and died horribly.

Right. It's that same

...Ok.

\section{The Completed Story}

123. Chloe: One day. One day a... This is our completed story. One day a man went fishing by the seaside because it was a nice and sunny day.

124. Seb:

125. Lottie:

126. Adam:

was a cat..

No! Seb wait..

No. that's fine . Go.

Carry on, want to write down.
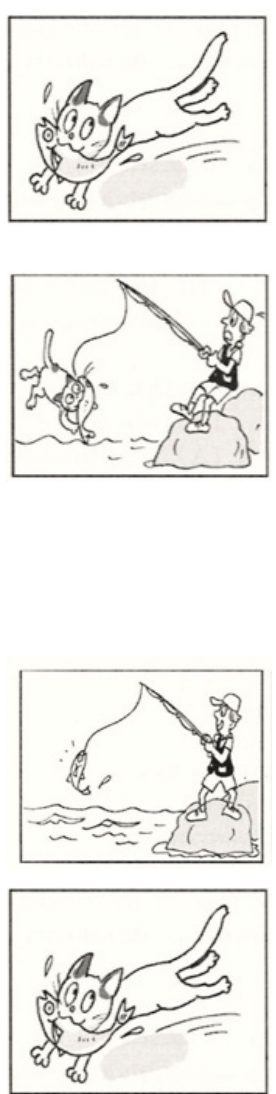
127. Seb:

128. Lottie:

129. Adam:

There was a cat with a fish in its mouth jumpin' about...

At his surprise, he didn't just catch a fish, he also caught a cat.

Eventually the cat let go, fell to its death, drowning horribly

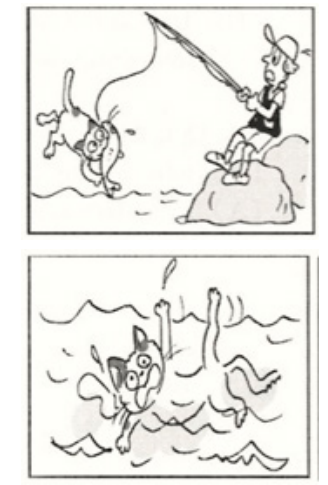

\section{Appendix B \\ Expressions}

What did you want to say?

Write down the phrases which you wanted to use.

\begin{tabular}{|c|c|c|c|}
\hline & Japanese & English & $\checkmark$ \\
\hline 1 & & & \\
\hline 2 & & & \\
\hline 3 & & & \\
\hline 4 & & & \\
\hline 5 & & & \\
\hline 6 & & & \\
\hline 7 & & & \\
\hline 8 & & & \\
\hline 9 & & & \\
\hline 10 & & & \\
\hline
\end{tabular}

Comment 